\title{
Unchanging diet in a stable colony: contemporary and past diet composition of black-legged kittiwakes Rissa tridactyla at Helgoland, south-eastern North Sea
}

\author{
Nele Markones • Nils Guse • Ommo Hüppop • \\ Stefan Garthe
}

Received: 26 August 2008 / Accepted: 17 February 2009 / Published online: 22 March 2009

(C) Springer-Verlag and AWI 2009

\begin{abstract}
In contrast to the situation at the west coast of the North Sea, the breeding colony of black-legged kittiwakes Rissa tridactyla at Helgoland in the south-eastern North Sea did not exhibit severe declines since 1990 but instead numbers increased and only lately stabilised. Declines at the west coast of the North Sea were attributed to a lower abundance and lower quality of the key prey, sandeels. We hypothesised that kittiwakes at Helgoland do not rely as heavily on sandeels as their conspecifics. We analysed stomach contents of nestlings and adults of 2001, 2002, 2004 and 2006. In concordance with earlier studies of the 1980s and 1990s, young whiting Merlangius merlangus was the most important prey species in 2001, 2002 and 2004. Clupeids and sandeels were consumed in lower proportions. While earlier studies suggested whiting to originate from fisheries discards, evidence now supports that kittiwakes prey upon whiting in areas of hydrographic fronts. No whiting was recovered in samples of 2006 and the proportion of fish prey was low. Main prey items were polychaete worms (Nereidae), which were presumably consumed as swarming Heteronereis stages. An observed strong rise in water temperature in summer 2006 might have influenced food availability of kittiwakes by inducing
\end{abstract}

Communicated by H.-D. Franke.

N. Markones $(\bowtie) \cdot$ N. Guse $\cdot$ S. Garthe Research and Technology Centre (FTZ), University of Kiel, Hafentörn 1, 25761 Büsum, Germany e-mail: markones@ftz-west.uni-kiel.de

\section{O. Hüppop}

Institut für Vogelforschung "Vogelwarte Helgoland", Inselstation, P. O. Box 1220, 27494 Helgoland, Germany swarming of Nereidae. Overall, kittiwakes breeding on Helgoland showed a positive population trend for several decades while mainly feeding on whiting.

Keywords Black-legged kittiwake Rissa tridactyla . Diet $\cdot$ North Sea $\cdot$ Whiting Merlangius merlangus

\section{Introduction}

In the North Sea, breeding numbers of black-legged kittiwakes Rissa tridactyla (hereafter 'kittiwakes') have declined by more than 50\% since 1990 (Frederiksen et al. 2004; Heubeck 2004). In most areas, a distinct decrease of breeding success has been recorded (Wanless et al. 2005; ICES-WGSE 2006), which was probably connected to low food availability and low food quality (Frederiksen et al. 2004; Wanless et al. 2005, 2007). The kittiwake's surfacefeeding foraging technique restricts it to prey concentrations at the sea surface and thus renders this species more vulnerable to food reductions than most other seabird species (Monaghan 1996; Furness and Tasker 2000). The insufficient food availability, which has also led to breeding failure and negative population trends of other seabird species (Mavor et al. 2005), is assumed to result mainly from ecosystem changes (Heubeck 2004). At the Isle of May, breeding success and population trend of kittiwakes was strongly influenced by the availability of sandeel (Frederiksen et al. 2004). In the last decades, mean water temperature in winter has increased, leading to depressed recruitment of sandeels (Arnott and Ruxton 2002). Moreover, a stronger inflow of warm water from the Atlantic led to changes in phytoplankton communities which resulted in deteriorated food availability for sandeel larvae (Beaugrand 2004; Wanless et al. 2007). 
In the south-eastern North Sea, kittiwakes occupy a single colony that in 2007 hosted approximately 7,500 breeding pairs on the small offshore island Helgoland $\left(54^{\circ} 11^{\prime} \mathrm{N}\right.$, $\left.7^{\circ} 53^{\prime} \mathrm{E}\right)$. Although oceanographic changes resulting in a warmer, more marine situation have been recorded in the sea area around Helgoland as well (Wiltshire and Manly 2004), neither elevated breeding failure nor a distinct decline of breeding numbers have been recorded for this colony so far. In contrast to other colonies, the breeding numbers of kittiwakes at Helgoland doubled since 1990. Thus, the situation of kittiwakes breeding in the south-eastern North Sea apparently is up to now favourable. As diet is regarded to be one of the key factors influencing breeding performance and trends in numbers, we assumed that the success of the kittiwakes breeding at Helgoland could be explained by analysing the diet of chicks and adults. In particular, we hypothesised that kittiwakes at Helgoland do not rely as heavily on sandeel as their conspecifics from the west coast of the North Sea.

\section{Materials and methods}

Population trend of the breeding colony on Helgoland

After about 150 years of absence most likely due to strong human persecution, kittiwakes recolonised Helgoland in 1938. Continuous data on breeding numbers are available since 1952 (Fleet 1984; Hüppop 1997). Numbers showed a strong increase especially during the 1970s, 1980s and 1990 s and reached a maximum of 8,600 pairs in 2001 . The following years showed a stagnation and lately indicate a slight decline (Fig. 1).

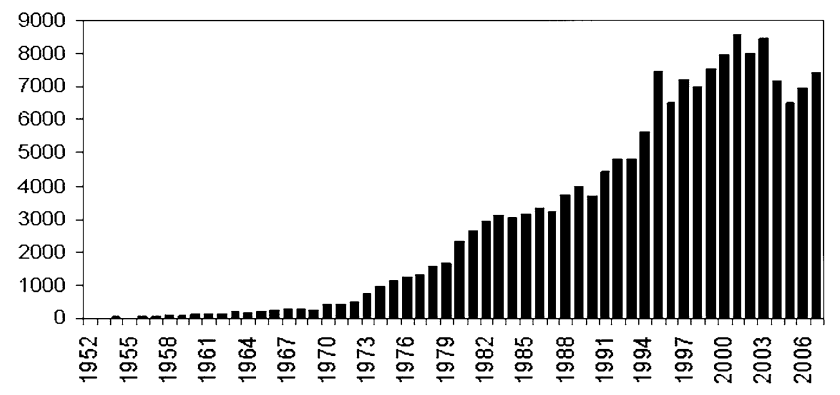

Fig. 1 Numbers of breeding black-legged kittiwakes on Helgoland from 1952 to 2007 (Data: O. Hüppop/IfV unpubl. data)
Samples

Samples consisted of chicks and adults found dead in the colony in the breeding seasons 2001, 2002, 2004 and 2006 (Table 1). Birds breed in highly eroding sandstone cliffs making nests inaccessible to humans and handling of birds to get diet samples only exceptionally possible. Killing of birds was not considered appropriate due to ethical reasons and conservation aspects. The majority of chicks presumably died due to falling out of the nest which is caused by accidents, e.g. resulting from antagonistic behaviour or unfavourable weather conditions. These birds die either directly from fractures or internal injuries or within the next days as adults do not continue to brood, feed or guard these chicks (Vauk-Hentzelt and Bachmann 1983). In 2002, all sampled chicks but one fell off the cliffs in the course of a heavy storm in early July. In 2006, an exceptional number of more than 100 chicks was found dead during a period of extremely high temperatures. A sub-sample only of these birds was analysed in the present study. Due to low sampling effort, no chicks were collected in 2003 and only one chick each was found in 2005 and 2007, which were not considered in the following analysis. The lungs of six adult birds were severely inflamed suggesting that these birds died from disease. Nevertheless, these birds possessed good fat depots and exhibited body masses in the range of healthy birds (350-430 g).

Analyses of stomach contents

Both samples of adults and chicks comprised $71 \%$ of stomachs which contained items classified as prey remains. Stomach contents were analysed following Leopold et al. (2000) and Guse (2005). Prey remains were identified to the lowest possible taxon (Ouwehand et al. 2004) by use of undigested hard-parts e.g. of fish skeletons, jaws of Nereidae, claws of crustaceans or chitinous remains of insects. Fish species were identified according to otoliths (Härkönen 1986; Leopold et al. 2001), urohyals, premaxillae, vertebrae and otic bullae (Watt et al. 1997; Leopold et al. 2001). Fish remains that could not be identified to species or family level were grouped as 'fish indet.'. We derived minimum numbers of prey individuals consumed by grouping remains. Thus, right and left hard-parts of the same species or family such as otoliths, premaxillae and nereid jaws were paired based on size, shape and wear.
Table 1 Number of stomach samples from the breeding colony of kittiwakes at Helgoland which were analysed in the present study

\begin{tabular}{|c|c|c|c|c|c|c|c|c|c|c|}
\hline & \multicolumn{3}{|l|}{2001} & \multicolumn{2}{|l|}{2002} & \multicolumn{2}{|l|}{2004} & \multicolumn{2}{|l|}{2006} & \multirow[t]{2}{*}{ Total } \\
\hline & June & July & August & June & July & June & July & June & July & \\
\hline Chicks & 5 & 21 & 3 & 0 & 20 & 11 & 22 & 4 & 19 & 105 \\
\hline Adults & 2 & 1 & 0 & 0 & 1 & 5 & 5 & 0 & 0 & 14 \\
\hline
\end{tabular}


Identification of prey remains and measurement of otoliths was performed using a stereo microscope in combination with an attached digital camera (Olympus SZH 10 Research Stereo and Olympus Camedia; Olympus, Hamburg, Germany) using Olympus DP-Soft v3.2 software (Olympus, Hamburg, Germany). We corrected for wear due to digestion by categorizing otoliths within wear classes and by multiplying size measurements of worn otoliths with correction factors to estimate original sizes (Leopold et al. 1998, 2001; Ouwehand et al. 2004). Total length of fish was calculated based on size measurements of otoliths by applying regressions between otolith length/width and total fish length obtained from Leopold et al. (2001). Subsequently, the fresh mass of fish was calculated based on regressions between total length and mass (Leopold et al. 2001). Biomass of individual fish identified by objects other than measurable otoliths was estimated based on available data of the respective prey species. We therefore calculated mean biomass values of each prey species separately for adults and chicks and separately for each year by bootstrapping the available data values applying 500 permutations (Efron and Tibshirani 1993).

Lengths of Nereidae were not calculated as jaws could not be identified to species level. Moreover, it was assumed that Nereidae were caught as swarming Heteronereis stages during their reproductive period. To our knowledge, no regression formulae are available for the calculation of total length of swarming stages on the basis of length of jaws. In addition, gulls preying on swarming Heteronereis stages mostly do not catch whole individuals but fragments only (N. Markones and N. Guse, personal observation, 2006).

\section{Results}

Stomach contents

Overall, diet composition of kittiwakes was dominated by fish prey. Fish did not only account for the maximum number of individual prey items but was also the most frequently consumed prey being found in $60 \%$ of the birds' stomachs. Exceptional in this aspect were the samples of 2006, which exhibited an occurrence of fish in only $39 \%$ of the stomachs.

The most frequent prey with respect to absolute numbers of prey individuals were polychaete worms of the family Nereidae with a total of at least 259 individuals based on recovered jaws. The majority of these Nereidae (206 ind. $=80 \%$ ) was found in a total of 16 stomachs of nestlings from 2006. During earlier years, nereid worms were less important both with respect to frequency of occurrence and absolute numbers.
In 2001, 2002 and 2004, gadoid fish comprising above all whiting Merlangius merlangus represented the most frequent prey by far, both with respect to frequency of occurrence and absolute numbers (Tables 2 and 3). Clupeids (Clupeidae) and sandeels (Ammodytidae) followed next, both showing the same moderate values of frequency of occurrence (Table 2). Fish species of other families as well as other prey species were only exceptionally recorded in single stomachs.

Fish length and biomass

Fish prey was on average rather small with a mean total fish length of $10.7 \mathrm{~cm}$ (median $=9.5 \mathrm{~cm})$ and a mean biomass of $11.5 \mathrm{~g}$ (median $=5.7 \mathrm{~g})$. Whiting, lesser sandeel Ammodytes marinus and great sandeel Hyperoplus sp. reached maximum lengths of $20-23 \mathrm{~cm}$. The maximum biomass value of $70 \mathrm{~g}$ was calculated for whiting (Table 3). Gadoids and especially whiting presented the most important prey when considering total biomass of prey fish calculated for the different years both for chicks and adults (Fig. 2). The proportion of the single fish families in the diet varied between years and differed between chicks and adults.

\section{Discussion}

Material and methodology

Results of stomach content analyses are sensitive to differences in digestibility of species-specific prey remains (Barrett et al. 2007). Otoliths of clupeids e.g. are smaller and more delicate compared to otoliths of similar-sized gadoids and thus are digested within a shorter period of time (see Brugger 1992). Thus, gadoids have a higher probability of being recovered, leading to a possible overestimation of their importance regarding diet composition. However, the majority of gadoid otoliths recovered in the present study was rather pristine and otoliths were often recovered along with vertebrae and other bones of gadoids, indicating a fresh meal. In conclusion, we are confident that bias due to differing digestibility did not constrain our principal result of whiting being the major prey in the study years 20012004.

The fact that our samples consist of birds that had died due to accident or disease leads to the question whether our results correspond to natural diet composition of healthy birds. Adult birds showing signs of lung infections were well nourished suggesting that foraging behaviour was not affected by the disease. With respect to chick samples, it could be argued that only chicks fed with lower quality food died while chicks fed with food of higher quality faced a lower risk of death. Although whiting is not as energy rich 
Table 2 Frequency of occurrence of prey items in stomachs of kittiwake nestlings and adults

\begin{tabular}{|c|c|c|c|c|c|c|c|c|c|}
\hline & \multicolumn{2}{|l|}{2001} & \multicolumn{2}{|l|}{2002} & \multicolumn{2}{|l|}{2004} & \multirow{2}{*}{$\begin{array}{l}2006 \\
N \text { chicks } \\
\text { (total } \\
N=19 \text { ) }\end{array}$} & \multicolumn{2}{|c|}{ 2001-2006 } \\
\hline & $\begin{array}{l}N \text { chicks } \\
\text { (total } \\
N=16 \text { ) }\end{array}$ & $\begin{array}{l}N \text { adults } \\
\text { (total } \\
N=3 \text { ) }\end{array}$ & $\begin{array}{l}N \text { chicks } \\
\text { (total } \\
N=13 \text { ) }\end{array}$ & $\begin{array}{l}N \text { adults } \\
\text { (total } \\
N=1 \text { ) }\end{array}$ & $\begin{array}{l}N \text { chicks } \\
\text { (total } \\
N=26 \text { ) }\end{array}$ & $\begin{array}{l}N \text { adults } \\
\text { (total } \\
N=6 \text { ) }\end{array}$ & & $\begin{array}{l}N \text { chicks } \\
\text { (total } \\
N=74 \text { ) }\end{array}$ & $\begin{array}{l}\text { Proportion } \\
(\%)\end{array}$ \\
\hline Gadidae & 12 & 2 & 7 & 1 & 21 & 5 & 0 & 40 & 54 \\
\hline $\begin{array}{l}\text { Whiting } \\
\text { Merlangius } \\
\quad \text { merlangus }\end{array}$ & 8 & 1 & 5 & 1 & 14 & 5 & 0 & 27 & 37 \\
\hline $\begin{array}{l}\text { Poor cod } \\
\quad \text { Trisopterus } \\
\quad \text { minutus }\end{array}$ & 0 & 0 & 0 & 0 & 2 & 0 & 0 & 2 & 3 \\
\hline Gadoid indet. & 6 & 1 & 2 & 0 & 8 & 0 & 0 & 16 & 22 \\
\hline Ammodytidae & 1 & 3 & 6 & 0 & 3 & 1 & 6 & 16 & 22 \\
\hline $\begin{array}{l}\text { Lesser sandeel } \\
\text { Ammodytes marinus }\end{array}$ & 0 & 1 & 1 & 0 & 0 & 1 & 3 & 4 & 5 \\
\hline $\begin{array}{l}\text { Great sandeel } \\
\quad \text { Hyperoplus sp. }\end{array}$ & 0 & 0 & 1 & 0 & 0 & 0 & 0 & 1 & 1 \\
\hline Sandeel indet. & 1 & 2 & 4 & 0 & 3 & 1 & 3 & 11 & 15 \\
\hline Clupeidae & 7 & 1 & 1 & 0 & 3 & 2 & 5 & 16 & 22 \\
\hline $\begin{array}{l}\text { Herring } \\
\text { Clupea harengus }\end{array}$ & 1 & 1 & 0 & 0 & 2 & 2 & 1 & 4 & 5 \\
\hline $\begin{array}{l}\text { Sprat } \\
\text { Sprattus sprattus }\end{array}$ & 2 & 0 & 0 & 0 & 1 & 1 & 2 & 5 & 7 \\
\hline Clupeid indet. & 6 & 0 & 1 & 0 & 1 & 0 & 2 & 10 & 14 \\
\hline Pleuronectiformes & 0 & 0 & 0 & 0 & 0 & 1 & 0 & 0 & 0 \\
\hline $\begin{array}{l}\text { Dab } \\
\text { Limanda limanda }\end{array}$ & 0 & 0 & 0 & 0 & 0 & 1 & 0 & 0 & 0 \\
\hline $\begin{array}{l}\text { Scaldfish } \\
\quad \text { Arnoglossus } \\
\quad \text { laterna }\end{array}$ & 0 & 0 & 0 & 0 & 0 & 1 & 0 & 0 & 0 \\
\hline Flatfish indet. & 0 & 0 & 0 & 0 & 0 & 1 & 0 & 0 & 0 \\
\hline $\begin{array}{l}\text { Anchovy Engraulis } \\
\text { encrasicolus }\end{array}$ & 0 & 1 & 0 & 0 & 0 & 1 & 0 & 0 & 0 \\
\hline $\begin{array}{l}\text { Goby indet. } \\
\text { (Gobiidae) }\end{array}$ & 0 & 1 & 0 & 0 & 0 & 0 & 0 & 0 & 0 \\
\hline $\begin{array}{l}\text { Wrasse indet. } \\
\text { (Labridae) }\end{array}$ & 0 & 0 & 0 & 0 & 1 & 0 & 0 & 1 & 1 \\
\hline Fish indet. & 3 & 1 & 1 & 0 & 4 & 1 & 0 & 8 & 11 \\
\hline $\begin{array}{r}\text { Nereidae indet. } \\
\text { (Polychaeta) }\end{array}$ & 0 & 0 & 3 & 0 & 3 & 1 & 16 & 22 & 30 \\
\hline $\begin{array}{l}\text { Coleoptera indet. } \\
\text { (Insecta) }\end{array}$ & 0 & 1 & 0 & 0 & 0 & 0 & 1 & 1 & 1 \\
\hline $\begin{array}{l}\text { Brachyura indet. } \\
\text { (Crustacea) }\end{array}$ & 1 & 0 & 0 & 0 & 1 & 0 & 1 & 3 & 4 \\
\hline
\end{tabular}

The categories of Gadidae, Ammodytidae, Clupeidae and Pleuronectiformes (only Bothidae and Pleuronectidae) combine results of all identified and unidentified (indet.) species of the respective family as given below

$N$ Number of stomachs containing the respective prey item; Total $N$ Total number of stomachs with prey items; Proportion Proportion of stomachs containing the respective prey item of the total number of stomachs with prey items

as clupeids (herring e.g. $6.5 \mathrm{~kJ} / \mathrm{g}$, Garthe et al. 1996), it is comparable to lesser sandeel with respect to nutrient composition and energy density (whiting: $4.41 \mathrm{~kJ} / \mathrm{g}$, lesser sandeel: $4.63 \mathrm{~kJ} / \mathrm{g}$, Hilton et al. 2000). Results of dissections showed that the majority of chicks most probably died directly from fractures and injuries caused by their fall from the nest and not due to malnourishment. Diet composition of the chicks of 2002 which all fell from the cliffs during a heavy storm, i.e. got killed in an accident, did not differ substantially from chick samples of other study years (see Fig. 2). Moreover, 
Table 3 Occurrence, length $(\mathrm{cm})$ and biomass ( $\mathrm{g}$ ) of fish prey found in stomachs of kittiwake nestlings and adults at Helgoland in 2001, 2002, 2004 and 2006

\begin{tabular}{|c|c|c|c|c|c|c|c|c|c|c|c|c|}
\hline & \multirow{2}{*}{$\begin{array}{l}\text { Median } \\
\text { no. }\end{array}$} & \multirow{2}{*}{$\begin{array}{l}\text { Max } \\
\text { no. }\end{array}$} & \multirow[t]{2}{*}{$N$} & \multirow[t]{2}{*}{$N_{\mathrm{o}}$} & \multicolumn{2}{|c|}{ Median fish length } & \multicolumn{2}{|c|}{ Range fish length } & \multicolumn{2}{|c|}{ Median biomass } & \multicolumn{2}{|c|}{ Range biomass } \\
\hline & & & & & Chicks & Adults & Chicks & Adults & Chicks & Adults & Chicks & Adults \\
\hline Whiting Merlangius merlangus & 2 & 17 & 113 & 86 & 8 & 10 & $6-21$ & $5-21$ & 4 & 6 & $1-70$ & $1-68$ \\
\hline Poor cod Trisopterus minutus & 1 & 1 & 2 & 2 & 14 & - & $13-15$ & - & 31 & - & $25-38$ & - \\
\hline Gadoid indet. & 1 & 4 & 21 & 3 & 12 & - & $9-15$ & - & 12 & - & $5-25$ & - \\
\hline Lesser sandeel Ammodytes marinus & 1 & 2 & 7 & 7 & 15 & 15 & $13-20$ & $15-16$ & 9 & 11 & $7-23$ & $9-12$ \\
\hline Great sandeel Hyperoplus sp. & 2 & 2 & 2 & 2 & 22 & - & $21-23$ & - & 27 & - & $23-30$ & - \\
\hline Sandeel indet. & 1 & 4 & 19 & 7 & 14 & 21 & $13-17$ & $21-21$ & 9 & 30 & $6-13$ & $30-31$ \\
\hline $\begin{array}{l}\text { Herring } \\
\text { Clupea harengus }\end{array}$ & 1 & 3 & 9 & 6 & 9 & 11 & $9-10$ & $9-14$ & 5 & 11 & $4-6$ & $4-17$ \\
\hline $\begin{array}{l}\text { Sprat } \\
\text { Sprattus sprattus }\end{array}$ & 2.5 & 3 & 13 & 12 & 10 & 11 & $6-13$ & $11-12$ & 8 & 11 & $7-18$ & $9-13$ \\
\hline Clupeid indet. & 1 & 2 & 12 & 5 & 9 & - & $6-9$ & - & 4 & - & $1-5$ & - \\
\hline Scaldfish Arnoglossus laterna & 4 & 4 & 4 & 4 & - & 9 & - & $7-11$ & - & 8 & - & $3-13$ \\
\hline Anchovy Engraulis encrasicolus & 1 & 1 & 2 & 1 & - & 15 & - & - & - & 18 & - & - \\
\hline Goby Pomatoschistus sp. & 1 & 1 & 1 & 1 & - & 6 & - & - & - & 2 & - & - \\
\hline
\end{tabular}

Fish length and biomass were calculated based on otoliths and thus could not be derived for individuals, e.g. one Dab and one wrasse, identified according to objects other than otoliths

Median no. minimum number of individual fish per stomach containing remains of the respective prey species; Max no. Maximum number of individuals per stomach; $N$ Total number of individuals recovered according to otoliths and other prey remains; $N_{o}$ Total number of individual fish used for calculations of fish length and biomass

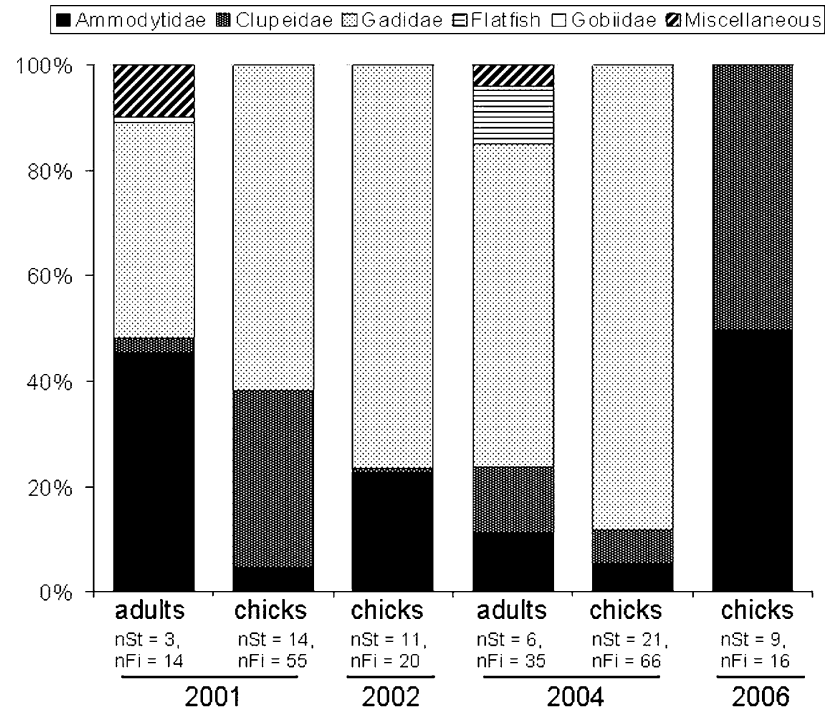

Fig. 2 Yearly variation in relevance of the main fish families in the diet of kittiwake nestlings and adults based on calculations of total biomass. $n S t$ number of stomachs containing fish remains used for calculations of biomass; $n F i$ number of individual fish used for calculations of biomass; see "Materials and methods" for details of calculations. The results of one adult kittiwake from 2001 are not shown due to low sample size $(\mathrm{nSt}=1, \mathrm{nFi}=1)$. Note that all chicks of 2002 fell from the cliffs during a heavy storm, i.e. got killed in an accident

recent pellet analyses from the breeding season 2008 showed that diet composition of living healthy adult birds also consisted predominantly of whiting (N. Markones, unpublished data). In conclusion, we found neither an indication that whiting represents a low-quality food that might cause higher probability of falling from the nest nor did we find an indication that diet composition of birds sampled differed from living healthy birds.

Comparison to earlier studies

The diet composition in the years 2001, 2002 and 2004 assessed in this study corresponds well to earlier studies on food of kittiwake nestlings at Helgoland (Table 4). With the exception of 2006, whiting was always the major or one of the main prey species in the diet of chicks at Helgoland. Moreover, the size of fish consumed was more or less the same over the different study periods, implying that mostly whiting of age class 0 were preyed upon (following agelength relationships described by Knijn et al. 1993).

Whiting: discard or natural prey?

As gadoids are generally classified as demersal fish species (Muus and Nielsen 1999), whiting and other gadoid species were believed not to be naturally available for the surfacefeeding kittiwake, which reaches a maximum diving depth of 1-2 m only during surface plunging (Burtt 1974). Earlier studies consequently assumed whiting to be mainly accessible to kittiwakes in form of fisheries discard (Vauk-Hentzelt and Bachmann 1983; Prüter 1989; Maul 1994). Thus, 
Table 4 Comparison of present results with previous studies: occurrence of fish remains, main prey species and length and biomass of consumed whiting in the diet of kittiwakes at Helgoland according to food remains in stomach samples

\begin{tabular}{|c|c|c|c|c|c|}
\hline Period & $\begin{array}{l}N \text { stomach } \\
\text { samples }\end{array}$ & $\begin{array}{l}\text { Stomachs } \\
\text { containing } \\
\text { fish remains }(\%)\end{array}$ & Main prey species & Length of whiting consumed & Source \\
\hline 1980-1982 & 113 & 78 & $\begin{array}{l}\text { Saithe/haddock, } \\
\text { whiting }\end{array}$ & Min-max: 6-13 cm & $\begin{array}{l}\text { Vauk-Hentzelt } \\
\text { and Bachmann (1983) }\end{array}$ \\
\hline 1983-1985 & 560 & 97 & Sandeels, whiting & $\varnothing 16 \mathrm{~cm}(\min -\max :<10-23 \mathrm{~cm})$ & Prüter (1989) \\
\hline 1990-1992 & 320 & 63 & Whiting & $\emptyset 13 \mathrm{~cm}(\min -\max : 7-22 \mathrm{~cm})$ & Maul (1994) \\
\hline 2001 & 29 & 64 & Whiting & $\varnothing 8 \mathrm{~cm}(\min -\max : 6-13 \mathrm{~cm})$ & This study \\
\hline 2002 & 20 & 67 & Whiting & $\emptyset 20 \mathrm{~cm}(\min -\max : 19-21 \mathrm{~cm})$ & This study \\
\hline 2004 & 33 & 81 & Whiting & $\varnothing 9 \mathrm{~cm}(\min -\max : 6-19 \mathrm{~cm})$ & This study \\
\hline 2006 & 23 & 43 & Nereidae & Not found & This study \\
\hline
\end{tabular}

All results refer to nestlings with the exception of the period 1990-1992 that contains data of 11 adults additionally (Maul 1994). Stomachs containing fish remains are given in \% of stomachs with any contents (=stomachs containing dietary remains plus stomachs containing other objects)

Saithe, Pollachius virens; haddock, Melanogrammus aeglefinus

kittiwakes were believed to rely heavily on fisheries and to be highly vulnerable to reductions in this anthropogenic food source (Camphuysen et al. 1995). However, only a very low percentage of kittiwakes was actually observed at fishing vessels in the German Bight $(<5 \%$, Jan-Dec 19902006, German Seabirds at Sea database v5.07). Instead, analyses of dedicated cruises depicted an association of kittiwakes with hydrographic fronts during summer (Markones 2007). Most interestingly, young whiting $(<15 \mathrm{~cm}$ total length) were found to concentrate in frontal areas of the North Sea (Floeter 2005). In summer, the German Bight represents one of the concentration areas of juvenile whiting within the North Sea (http://www.ices.dk/marineworld/ fishmap/ices/pdf/whiting.pdf) and dense schools of juvenile whiting have been recorded in the upper water column of the sea area around Helgoland in August 2004 in the course of a fisheries research cruise (D. Stepputtis, personal communication, 2006). These findings lead to the assumption that juvenile whiting are indeed available in high concentrations near the sea surface in frontal areas of the German Bight, where they can be preyed upon by foraging kittiwakes. Consequently, we consider whiting in the diet of kittiwakes at Helgoland to originate from a natural feeding area independent of commercial fishing activities.

\section{Diet composition in 2006}

Our samples of 2006 comprise three unusual aspects contrasting earlier results: (1) An exceptionally high number of chicks died within a few days although weather conditions were not stormy. (2) No whiting was found. (3) The main prey item according to stomach contents were polychaetes (Nereidae). Nereidae are benthic polychaetes and thus are like benthic fish usually out of reach for surface-feeding kittiwakes. During reproduction, however, most Nereidae evolve epitokous Heteronereis stages swarming in the surface layers which simultaneously release gametes within a few days ('epidemic spawning', Watson et al. 2000).

It may be speculated that a single factor, i.e. temperature, influenced both availability of Nereidae and caused high mortality of kittiwake chicks. In the respective period, high temperature of air and water was recorded with sea surface temperature in the German Bight rising above $19^{\circ} \mathrm{C}$ and temperature at the sea bottom around Helgoland rising above $17^{\circ} \mathrm{C}$ (Wegner 2007). Temperature of the seabird breeding cliffs which are mainly oriented to SW presumably reached extremely high values. Direct radiation and high temperatures constrain thermoregulatory abilities and cause heat stress both in adults and chicks of kittiwakes. Under such circumstances, parent birds are forced to leave the nest, leading to death of chicks due to heat stress or lack of food (Barrett and Runde 1980). On the other hand, suddenly raised temperatures can trigger swarming in polychaetes (Hardege et al. 1990). With regard to frequency of occurrence and numbers of Nereidae found in kittiwake stomachs in 2006, which were all collected within four successive days, it is highly probable that kittiwakes preyed upon swarming Heteronereis stages occurring ephemerally at the sea surface. However, it remains unclear whether swarming was actually induced by the observed rise in temperature or whether it was triggered by other parameters, e.g. the lunar cycle (Watson et al. 2000). In conclusion, superabundance of swarming Nereidae might explain diet composition of kittiwake nestlings in July 2006.

\section{Conclusions}

In confirmation of our hypothesis, the kittiwakes of the breeding colony at Helgoland do not depend as strongly on 
sandeels as their conspecifics from the west coast of the North Sea which suffer severe declines in breeding numbers. The combination of present results and earlier studies showed that kittiwakes at Helgoland were performing well while consuming predominantly whiting for several decades.

Differing trends for marine prey stocks in the southern and the north-western part of the North Sea are also indicated by an exceptionally high abundance of seabirds and marine mammals in the southern North Sea in recent years (Camphuysen 2006). For the latter group this phenomenon can particularly be observed for Harbour Porpoises Phocoena phocoena which showed a long-term shift in their main concentration area from the northern to the southern North Sea between 1994 and 2005 (Hammond and Macleod 2006). Following Clark and Frid (2001), distinct ecosystem changes in the northern, western and central part of the North Sea are generally mainly caused by climatic changes while ecosystem changes in the southern and eastern part are predominantly driven by changes in nutrient input from anthropogenic sources. Thus, current climatic changes like increasing temperatures probably led to reductions in food availability for seabirds and marine mammals in the northern part of the North Sea but presumably did not cause significant changes in the southern part. It remains unclear, however, whether the latter will persist to provide good foraging grounds for marine top predators or whether comparable ecosystem changes in this region will become evident after a certain time lag. Like seabird research in the north-western North Sea, future studies of breeding numbers, breeding performance and diet composition of kittiwakes at Helgoland could provide the potential to evaluate the situation of marine prey stocks in the German Bight and to identify major ecosystem changes.

Acknowledgments Samples were collected by co-workers of the Institut für Vogelforschung „Vogelwarte Helgoland”, Inselstation. Henriette Dries, Jan Guse, Dennis Münd, Jessica Garzke, Nicole Sonntag, Axinja Stark and Natalie Troper assisted in dissections and prepared stomach samples for analyses. Okka Jansen and Mardik Leopold (IMARES, Texel) were instrumental in identification of fish remains. Andreas Dänhardt (IfV/Terramare Wilhelmshaven), Siegfried Ehrich (ISH, BFAFi Hamburg), Jens Floeter (University of Hamburg) and Daniel Stepputtis (IfM-Geomar Kiel/IOR) provided information on fish occurrence and behaviour. Ingrid Kröncke (Senckenberg Institute, Wilhelmshaven), Jennifer Dannheim (AWI, Bremerhaven) and Kees Camphuysen (NIOZ, Texel) provided information on occurrence and behaviour of Nereidae. Sven Adler gave valuable statistical support. Comments and suggestions from the anonymous reviewers and Jochen Krause and Thomas Merck (German Federal Agency for Nature Conservation) have greatly contributed to improving earlier drafts of this paper. The German Federal Agency for Nature Conservation (Diet project) and the Federal Environmental Ministry Germany (MINOSplus project) supported the analysis of samples and data processing financially.

\section{References}

Arnott SA, Ruxton GD (2002) Sandeel recruitment in the North Sea: demographic, climatic and trophic effects. Mar Ecol Prog Ser 238:199-210

Barrett RT, Runde OJ (1980) Growth and survival of nestling kittiwakes Rissa tridactyla in Norway. Ornis Scand 11:228-235

Barrett RT, Camphuysen CJ, Anker-Nilssen T, Chardine JW, Furness RW, Garthe S, Hüppop O, Leopold MF, Montevecchi WA, Veit RR (2007) Diet studies of seabirds: a review and recommendations. ICES J Mar Sci 64:1675-1691

Beaugrand G (2004) The North Sea regime shift: evidence, causes, mechanisms and consequences. Prog Oceanogr 60:245-262

Brugger KE (1992) Differential digestabilities of channel catfish, bluegill, and gizzard shad: in vitro standards for gastric digestion by seabirds. Colon Waterbirds 15:257-260

Burtt EH (1974) Success of two feeding methods of the black-legged kittiwake. Auk 91:827-829

Camphuysen CJ (2006) Seabirds and marine mammals in the southern Bight, 1960-2005: major distributional shifts as a result of... poor conditions elsewhere? The seabird group 9th international conference "seabird populations under pressure", Aberdeen, Scotland

Camphuysen CJ, Calvo B, Durinck J, Ensor K, Follestad A, Furness RW, Garthe S, Leaper G, Skov H, Tasker ML, Winter CJN (1995) Consumption of discards by seabirds in the North Sea. Final report EC DG XIV research contract BIOECO/93/10. NIOZ Rapport 1995-5. Netherlands Institute for Sea Research, Texel

Clark RA, Frid CLJ (2001) Long-term changes in the North Sea ecosystem. Environ Rev/Dossiers Environ 9:131-187

Efron B, Tibshirani R (1993) An introduction to the Bootstrap. Chapman \& Hall, New York

Fleet D (1984) Changes in numbers of breeding kittiwakes in Helgoland. Ringing a migration 5:32-34

Floeter J (2005) An investigation of key processes affecting trophic interactions in the North Sea fish assemblage and their significance for multi species fisheries assessment. $\mathrm{PhD}$ thesis, University of Hamburg

Frederiksen M, Wanless S, Harris MP, Rothery P, Wilson LJ (2004) The role of industrial fisheries and oceanographic change in the decline of North Sea black-legged kittiwakes. J Appl Ecol 41:1129-1139

Furness RW, Tasker ML (2000) Seabird-fishery interactions: quantifying the sensitivity of seabirds to reductions in sandeel abundance, and identification of key areas for sensitive seabirds in the North Sea. Mar Ecol Prog Ser 202:253-264

Garthe S, Camphuysen CJ, Furness RW (1996) Amounts of discards by commercial fisheries and their significance as food for seabirds in the North Sea. Mar Ecol Prog Ser 136:1-11

Guse N (2005) Diet of a piscivorous top predator in the Baltic Seathe red-throated diver (Gavia stellata) in the Pomeranian Bight. Diploma thesis, University of Kiel

Hammond PS, Macleod K (2006) Scans II-Report on progress. Document for ASCOBANS Meeting of Parties, Egmond aan Zee, September 2006

Hardege JD, Bartels-Hardege HD, Zeeck E, Grimm FT (1990) Induction of swarming of Nereis succinea. Mar Biol 104:291-295

Härkönen T (1986) Guide to the otoliths of the bony fishes of the Northeast Atlantic. Danbiu Aps, Hellerup

Heubeck M (2004) Black-legged kittiwake Rissa tridactyla. In: Mitchell PI, Newton SF, Ratcliffe N, Dunn TE (eds) Seabird populations of Britain and Ireland. T. \& A.D. Poyser, London, pp 277-290

Hilton GM, Furness RW, Houston DC (2000) A comparative study of digestion in North Atlantic seabirds. J Avian Biol 31:36-46

Hüppop O (1997) Langzeit-Veränderungen der Brutbestände Helgoländer See- und Küstenvögel. Seevögel 18:38-44 
ICES-WGSE (2006) Report of the working group on seabird ecology. ICES CM 2006/LRC:08, Ref. ACE, ACME, 86pp

Knijn RJ, Boon TW, Heessen HJL, Hislop JRG (1993) Atlas of North Sea Fishes. ICES Coop Res Rep 194, Copenhagen, Denmark

Leopold MF, van Damme CJG, van der Veer HW (1998) Diet of cormorants and the impact of cormorant predation on juvenile flatfish in the Dutch Wadden Sea. J Sea Res 40:93-107

Leopold MF, van Leeuwen PW, Horn H, Camphuysen CJ (2000) Grote Ijsduiker Gavia immer eet kleine visjes: een verdronken vogel geeft geheimen prijs. Limosa 73:135-143

Leopold MF, van Damme CJG, Philippart CJM, Winter CJN (2001) Otoliths of North Sea fish: interactive guide of identification of fish from the SE North Sea, Wadden Sea and adjacent fresh waters by means of otoliths and other hard parts. CD-Rom, ETI, Amsterdam

Markones N (2007) Habitat selection of seabirds in a highly dynamic coastal sea: temporal variation and influence of hydrographic features. $\mathrm{PhD}$ thesis, University of Kiel

Maul AM (1994) Ernährungsweisen und Brutbiologie der Dreizehenmöwe Rissa tridactyla (Linnaeus, 1758) auf Helgoland. Diploma thesis, University of Graz

Mavor RA, Parsons M, Heubeck M, Schmitt S (2005) Seabird numbers and breeding success in Britain and Ireland, 2004. Joint Nature Conservation Committee, Peterborough, UK

Monaghan P (1996) Relevance of the behaviour of seabirds to the conservation of marine environments. Oikos 77:227-237

Muus BJ, Nielsen JG (1999) Die Meeresfische Europas in Nordsee. Ostsee und Atlantik, Franckh-Kosmos, Stuttgart
Ouwehand J, Leopold MF, Camphuysen CJ (2004) A comparative study of the diet of guillemots Uria aalge and razorbills Alca tor$d a$ killed during the Tricolor oil incident in the south-eastern North Sea in January 2003. Atlantic Seabirds 6:147-164

Prüter J (1989) Phänologie und Ernährungsökologie der Dreizehenmöwen (Rissa tridactyla)-Brutpopulation auf Helgoland. Ökol Vögel 11:189-200

Vauk-Hentzelt E, Bachmann L (1983) Zur Ernährung nestjunger Dreizehenmöwen (Rissa tridactyla) aus der Kolonie des Helgoländer Lummenfelsens. Seevögel 4:42-45

Wanless S, Harris MP, Redman P, Speakman JR (2005) Low energy values of fish as a probable cause of a major seabird breeding failure in the North Sea. Mar Ecol Prog Ser 294:1-8

Wanless S, Frederiksen M, Daunt F, Scott BE, Harris MP (2007) Black-legged kittiwakes as indicators of environmental change in the North Sea: evidence from long-term studies. Prog Oceanogr 72:30-38

Watson GJ, Williams ME, Bentley MG (2000) Can synchronous spawning be predicted from environmental parameters? A case study of the lugworm Arenicola marina. Mar Biol 136:1003-1017

Watt J, Pierce GJ, Boyle PR (1997) Guide to the identification of North Sea fish using premaxillae and vertebrae. ICES Coop Res Rep 220

Wegner G (2007) "Die Nordsee ist so warm wie noch nie!"-Stimmen derartige Nachrichten? http://www.bfa-fish.de/nn_820254/DE/ aktuelles/aktuelles/2007/2007_06_08__Nordsee.html

Wiltshire KH, Manly BFJ (2004) The warming trend at Helgoland Roads, North Sea: phytoplankton response. Helgol Mar Res 58:269-273 